Review Article

\title{
lonizing radiation-induced DNA injury and damage detection in patients with breast cancer
}

\author{
Gissela Borrego-Soto ${ }^{1,2}$, Rocío Ortiz-López ${ }^{1,2}$ and Augusto Rojas-Martínez ${ }^{1,2}$ \\ ${ }^{1}$ Departamento de Bioquímica y Medicina Molecular, Facultad de Medicina, \\ Universidad Autónoma de Nuevo León, Monterrey, Nuevo León, Mexico. \\ ${ }^{2}$ Centro de Investigación y Desarrollo en Ciencias de la Salud, Universidad Autónoma de Nuevo León, \\ Monterrey, Nuevo León, Mexico.
}

\begin{abstract}
Breast cancer is the most common malignancy in women. Radiotherapy is frequently used in patients with breast cancer, but some patients may be more susceptible to ionizing radiation, and increased exposure to radiation sources may be associated to radiation adverse events. This susceptibility may be related to deficiencies in DNA repair mechanisms that are activated after cell-radiation, which causes DNA damage, particularly DNA double strand breaks. Some of these genetic susceptibilities in DNA-repair mechanisms are implicated in the etiology of hereditary breast/ovarian cancer (pathologic mutations in the BRCA 1 and 2 genes), but other less penetrant variants in genes involved in sporadic breast cancer have been described. These same genetic susceptibilities may be involved in negative radiotherapeutic outcomes. For these reasons, it is necessary to implement methods for detecting patients who are susceptible to radiotherapy-related adverse events. This review discusses mechanisms of DNA damage and repair, genes related to these functions, and the diagnosis methods designed and under research for detection of breast cancer patients with increased radiosensitivity.
\end{abstract}

Keywords: breast cancer, ionizing radiation, DNA damage, DNA double strand break, DNA repair analysis.

Received: January 19, 2015; Accepted: July 15, 2015.

\section{Background}

Breast cancer is the leading cause of cancer morbidity and death in women in developed countries and countries with emerging economies (Ripperger et al., 2009; Youlden et al., 2012). According to Globocan, 1.67 million new cases of breast cancer were diagnosed in 2012 and ranks as the fifth cause of death from cancer overall $(522,000$ deaths). A global increase has been estimated to around 16,500 yearly new cases of this neoplasia by 2020. (Knaul et al., 2009)

Radiation therapy is an efficient treatment for cancer. About $50 \%$ of patients with malignant breast tumors receive radiation therapy and most patients seem tolerate it, but some suffer severe adverse effects induced by the therapy. This variability of response may be caused by several factors, like age, life style, inflammatory responses, oxidative stress, genetic predisposition and variants in genes involved in the response to radiation-induced DNA damage

Send correspondence to Augusto Rojas-Martínez. Departamento de Bioquímica y Medicina Molecular, Facultad de Medicina, Universidad Autónoma de Nuevo León, Av. Francisco I. Madero y Dr. Eduardo Aguirre Pequeño s/n, Colonia Mitras Centro, Monterrey, Nuevo León, Mexico. E-mail: arojasmtz@gmail.com/ augusto.rojasm@uanl.mx.
(Smirnov et al., 2012; Hornhardt et al., 2014). Therefore, it is important to develop new diagnostic techniques for predicting responses to cancer treatment and for identifying patients susceptible to radiation-related toxicity.

Any disturbance that results in the loss of genomic integrity may induce cell cycle deregulation and uncontrolled cell proliferation. Cells are continuously exposed to DNA damaging agents and have developed mechanisms to respond to genome damage. Double-strand DNA breaks (DSB), although rare, are perhaps the most lethal mechanism and are often produced by ionizing radiation (Pastink et al., 2001; Siever et al., 2003). The BRCA-1 and BRCA-2 proteins are involved in DSB damage repair, and several mutations in these genes increase the risk for developing breast and other neoplasias (Roy et al., 2012).

\section{lonizing Radiation-Associated DNA Damage, Radiotherapy and Mechanisms of DNA Repair}

lonizing radiation effects in the cell

Ionizing radiation is a type of high-energy radiation that is able to release electrons from atoms and molecules generating ions which can break covalent bonds. Ionizing radiation directly affects DNA structure by inducing DNA 
breaks, particularly, DSBs. Secondary effects are the generation of reactive oxygen species (ROS) that oxidize proteins and lipids, and also induce several damages to DNA, like generation of abasic sites and single strand breaks (SSB). Collectively, all these changes induce cell death and mitotic failure.

Ionizing radiation can be divided into $\mathrm{X}$-rays, gamma rays, alpha and beta particles and neutrons. Quiescent and slowly dividing cells are less radiosensitive, like those constituting the nervous system, while cells with high proliferation rates are more radiosensitive, like bone marrow, skin, and epithelial cells of the gastro-intestinal tract, among others. The radiation dose is measured in units gray (Gy), a measure of the amount of radiation absorbed by $1 \mathrm{~kg}$ of tissue (Dunne-Daly, 1999).

\section{Radiotherapy}

Radiotherapy is a treatment aimed at shrinking the tumor mass or at eliminating residual tumor cells by exposing the tumor to ionizing radiation. Radiotherapy regimes mostly use X- and gamma radiation (Masuda and Kamiya, 2012). Radiation affects tumor and healthy irradiated cells indistinctly. Radiotherapy is used as the standard treatment for breast cancer after mastectomy; but this therapy may be also used prophylactically or palliatively to reduce the risk of tumor recurrence or to relieve symptoms caused by tumor growth and associated metastases, respectively (Delaney et al., 2005). Radiation therapy can be delivered by external-beam radiation or internal radiation. Externalbeam radiation therapy is created electronically by a linear accelerator which produces photon beams known as $\mathrm{X}$-rays, with electric potentials in the range of 4 to 20 mega Volts. Patients receive radiation doses in daily sessions for several weeks, and the radiation dose may be administered in three different schemes: accelerated fractionation, hyperfractionation and hypofractionation. Accelerated fractionation means a radiation scheme in which the total dose of radiation is divided into small doses, and the treatments are given more than once per day. The total dose of radiation is administered in a shorter period of time (fewer days) compared to standard radiation therapy (weeks). A reduction in the treatment time may reduce the repopulation of tumor cells, resulting in a better locoregional control. In hyperfractioned treatment, the total radiation dose is divided into smaller doses, and it is administered more than once a day; but in the same period as standard radiotherapy (days or weeks). Dose reduction may reduce the toxicity risk, although the total dose is increased. Hypofractionated radiation treatment is given once a day or less often. The total dose is divided into larger doses and is administered over a shorter period than standard radiotherapy. This scheme reduces patient visits and cost, and fewer side effects are noticed when compared to conventional radiation therapy.
The internal radiation therapy, also called brachytherapy, is released from gamma-radiation sources such as radioactive isotopes like ${ }^{60} \mathrm{Co}$ and ${ }^{137} \mathrm{Cs}$, which are placed within the patient's body. This type of radiation can deliver high doses of focalized radiation with an electric potential in the range of 0.6 to 1 megaVolt and causes less damage to normal tissues (Patel and Arthur, 2006).

\section{DNA repair after ionizing radiation}

Ionizing radiation causes DSBs directly, but in addition base damages due to indirect effects are also induced. This radiation causes formation of ROS (reactive oxygen species) which are indirectly involved in DNA damage. These ROS generates apurinic / apyrimidinic (abasic) sites in the DNA, SSBs, sugar moiety modifications, and deaminated adducted bases (Redon et al., 2010; Aparicio et al., 2014). When DNA is damaged, the repair machinery of the cell is activated and stops the cell cycle at specific control checkpoints to repair DNA damage and prevent continuation of the cycle. It is known that the intrinsic radiosensitivity of tumor cells is strongly influenced by the cells DSB repair capability (Mladenov et al., 2013). If tumor cells are able to efficiently repair the radiation damage, resistance to radiation develops, enabling cells to survive and replicate. If the damage remains unrepaired, these mechanisms induce programmed cell death or apoptosis to prevent accumulation of mutations in daughter cells (Deckbar et al., 2011; Guo et al., 2011).

As mentioned, ionizing radiation inevitably reaches normal tissue, inducing bystander effects in tumor-adjacent normal cells that may contribute to chromosomal aberrations and to increase the risk for new malignancies. High doses of radiation may produce toxicity and reduce the patient's prognosis (Brown et al., 2015). Individual radiation treatment based on DSB repair capability could predict toxicity to surrounding tissues, thereby improving treatment safety. DSB repair capability depends not just on gene integrity, but also on gene expression. In addition to germinal mutations affecting genes like $B R C A 1$ and 2 or other related genes, genetic and epigenetic mechanisms may reduce or abrogate the expression of genes involved in DSB repair (Bosviel, et al., 2012). The DNA repair capability could be relevant to decide on the appropriate treatment for cancer patients, and functional tests may provide valuable information for these clinical decisions.

\section{DSB repair pathways}

DSB repair is achieved in three ways: non-homologous end joining (NHEJ), conservative homologous recombination (HR) and single-strand alignment, also called non-conservative homologous recombination (SSA) (Langerak and Russell, 2011). HR is considered an error-free mechanism because it uses an undamaged DNA guide strand to repair the DSB, and the original DNA is reconstituted without loss of genetic information, but this mecha- 
nism proceeds slowly and is only exerted at the $\mathrm{S} / \mathrm{G} 2$ phases of the cell cycle. NHEJ and SSA are considered error-prone and mutagenic mechanisms because the processing of DNA ends may incur in loss or modification of genetic information at the repaired DSB ends. NHEJ is the most common mechanism of DSB repair in eukaryotic cells. In this mechanism, the DNA strands at the DSB are cut or modified, and the ends are ligated together regardless of homology, generating deletions or insertions. Although this process is error-prone, this mechanism can fix the DNA damage quickly, because it is not restricted to a single cell cycle phase, thus preventing increased genetic instability (Do et al., 2014). These mechanisms are detailed below and in the Figure 1. The main proteins involved in the early steps of DSB detection, chromatin remodeling and DNA repair are listed in Table 1.
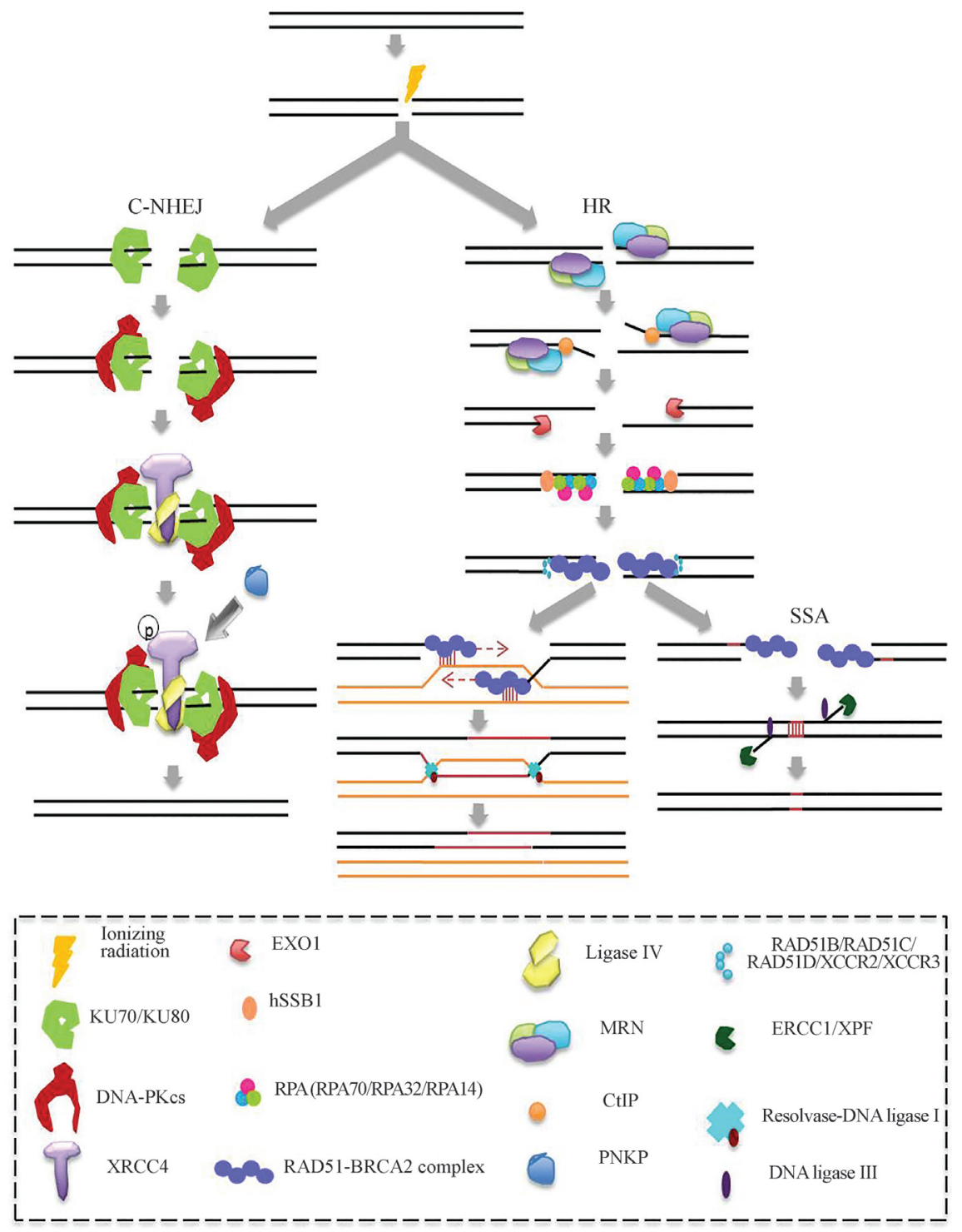

Figure 1 - DSB repair pathways. In NHEJ, the KU70/KU80 heterodimer binds to the DSB, protects it from degradation by exonucleases, and acts as a repressor of HR. The KU70/80 heterodimer recruits and activates the DNA-PKcs and KU70 interacts with XRCC4. Then, the DNA ligase IV interacts with the KU heterodimer to ligate the DNA ends. If required for ligation, PNKP binds to phosphorylated XRCC4 to process the DNA ends. In the HR pathway the MRN complex is recruited at the DSB ends and CtIP binds to the MRN complex activating an exonuclease activity which creates single strand segments at the borders of the DSB that are extended by the EXO1 3'- 5' exonuclease. Then, hSSB1 binds to free ends and RPA (an heterometic complex formed by RPA70, RPA32 and RPA14) protects against degradation. RPA is replaced by RAD51-BRCA2. RAD51 nucleoprotein searches for and invades the homologues sequences, from sister chromatid, to form a Holliday junction. The sister chromatids are joined by cohesin proteins to facilitate the interconnection of the DSB to the homologous recombination. Subsequently, RAD51 is removed leaving a free 3'-OH and DNA is synthesized by the DNA polymerase $\delta$ using the homologous chromatid as a template. Resolvase enzymes solve the Holliday junction and the DNA ends are joined by DNA ligase I. The SSA pathway is not conservative and depends on the presence of repeated sequences flanking the DSB. In this mechanism, the MRN complex joined to CtIP cleaves the 5'-end of one strand of DNA to expose microhomology sequences. Homologous sequences are aligned, while nonaligned regions are removed by the ERCC1/XPF nucleases. Then, DNA ends are joined by DNA ligase III. 
Table 1 - DNA repair and cell cycle control genes.

\begin{tabular}{|c|c|c|c|}
\hline Gene & Name & Function & $\begin{array}{l}\text { Cromosomal } \\
\text { location }\end{array}$ \\
\hline$A K T 1$ & $\begin{array}{l}\text { v-akt murine thymoma viral oncogene } \\
\text { homolog } 1\end{array}$ & $\begin{array}{l}\text { Serine/threonine kinase. Regulates components of the } \\
\text { apoptotic machinery. }\end{array}$ & $14 \mathrm{q} 32.32$ \\
\hline$A T M$ & Ataxia telangiectasia mutated & $\begin{array}{l}\text { Serine threonine protein kinase. Activates cell cycle check- } \\
\text { points upon DSB induction acting as a DNA damage sensor. }\end{array}$ & $11 \mathrm{q} 22-\mathrm{q} 23$ \\
\hline$B A P 1$ & $\begin{array}{l}\text { BRCA1 associated protein-1 (ubiquitin } \\
\text { carboxy-terminal hydrolase) }\end{array}$ & $\begin{array}{l}\text { Binds to BRCA1. Involved in cell cycle, response to DNA } \\
\text { damage and chromatin dynamics. }\end{array}$ & $3 \mathrm{p} 21.1$ \\
\hline$B I R P 1$ & $\begin{array}{l}\text { BRCA1 protein interaction with c-terminal } \\
\text { helicase }\end{array}$ & $\begin{array}{l}\text { Receptor-interacting protein forming a complex with } \\
\text { BRCA1. Active during DSB repair. }\end{array}$ & $17 \mathrm{q} 22.2$ \\
\hline$B R C A 1$ & Breast cancer 1 & $\begin{array}{l}\text { DNA repair, ubiquitination and transcriptional regulation to } \\
\text { maintain genomic stability. Induces cell cycle arrests after } \\
\text { ionizing irradiation. }\end{array}$ & $17 \mathrm{q} 21$ \\
\hline$B R C A 2$ & Breast cancer 2 & $\begin{array}{l}\text { Involved in DSB repair and/or homologous recombination in } \\
\text { meiosis. }\end{array}$ & $13 \mathrm{q} 12$ \\
\hline$C D K s$ & Cell Division Protein Kinase & Cell cycle kinases. & $10 \mathrm{q} 21.2$ \\
\hline$C D K N 1 B$ & Cyclin-dependent kinase inhibitor $1 \mathrm{~B}$ & Cell-cycle progression at G1. & $12 \mathrm{p} 13.1-\mathrm{p} 12$ \\
\hline$C C N D 1$ & Cyclin D1 & $\begin{array}{l}\text { Regulates cell cycle during } \mathrm{G} 1 / \mathrm{S} \text {, also interacts with a net- } \\
\text { work of repair proteins including RAD51 to regulate HR }\end{array}$ & $11 \mathrm{q} 13$ \\
\hline$C C N D 3$ & Cyclin D3 & Regulates G1/S transition in cell cycle & $6 \mathrm{p} 21.1$ \\
\hline$R B B P 8$ & Retinoblastoma Binding Protein & $\begin{array}{l}\text { Endonuclease that functions with MRX complex in the first } \\
\text { step of the DSB repair. }\end{array}$ & $18 \mathrm{q} 11.2$ \\
\hline EP300 & $300 \mathrm{kDa}$ E1A-Binding protein gene & $\begin{array}{l}\text { Regulates transcription via chromatin remodeling. Regulated } \\
\text { by acetylation in DNA damage response. }\end{array}$ & $22 \mathrm{q} 13.2$ \\
\hline EXO1 & Exonuclease 1 & 5'-3' Exonuclease & $1 \mathrm{q} 43$ \\
\hline$F G F R 2$ & Fibroblast growth factor receptor 2 & $\begin{array}{l}\text { Cell surface tyrosine kinase receptor regulating cell prolifer- } \\
\text { ation, migration and apoptosis. }\end{array}$ & $10 \mathrm{q} 25.3-\mathrm{q} 26$ \\
\hline$H I S T 1 H 2 B C$ & Histone cluster $1, \mathrm{H} 2 \mathrm{BC}$ & $\begin{array}{l}\text { Core histone playing roles in DNA repair, replication and } \\
\text { chromosomal stability. }\end{array}$ & $6 \mathrm{p} 22.1$ \\
\hline$H 2 A X$ & H2A Histone Family, Member X & $\begin{array}{l}\text { Required for checkpoint-mediated arrest of cell cycle pro- } \\
\text { gression in response to low doses of ionizing radiation and } \\
\text { for efficient DSB repair when modified by C-terminal } \\
\text { phosphorylation. }\end{array}$ & $11 \mathrm{q} 23.3$ \\
\hline KU70 & Thyroid Autoantigen $70 \mathrm{kDa}$ & $\begin{array}{l}\text { Binding to DSB ends and inhibition of exonuclease activity } \\
\text { at these ends. }\end{array}$ & $22 \mathrm{q} 13.2$ \\
\hline$L I G 4$ & Ligase IV & $\begin{array}{l}\text { DNA ligase involved in DNA non-homologous end joining } \\
\text { (NHEJ) required for DSB repair. }\end{array}$ & $13 \mathrm{q} 33.3$ \\
\hline$L S P 1$ & Lymphocyte-specific protein 1 & Actin binding protein $\mathrm{F}$. & $11 \mathrm{p} 15.5$ \\
\hline$M D C 1$ & Mediator of DNA Damage Checkpoint 1 & $\begin{array}{l}\text { Mediator-adaptor protein in response to DNA damage, active } \\
\text { during the } \mathrm{S} \text { and } \mathrm{G} 2 / \mathrm{M} \text { phases of cell cycle. }\end{array}$ & $6 \mathrm{p} 21.3$ \\
\hline$M L L 3$ & $\begin{array}{l}\text { Myeloid/lymphoid or mixed-lineage leukae- } \\
\text { mia } 3\end{array}$ & $\begin{array}{l}\text { Part of the ASCOM complex regulated by acetylation to in- } \\
\text { duce expression of p } 53 \text { targets such as p } 21 \text { in DNA damage } \\
\text { response. }\end{array}$ & $7 \mathrm{q} 36.1$ \\
\hline MRE11 & Meiotic Recombination 11 & Endonuclease, exonuclease, MRN/X complex-5. & $11 \mathrm{q} 21$ \\
\hline$N B N 1$ & Nibrin & $\begin{array}{l}\text { Component of the MRN/X complex. Plays a critical role in } \\
\text { the cellular response to DNA damage and the maintenance of } \\
\text { chromosome integrity. Regulator of cell cycle checkpoints in } \\
\text { meiosis. }\end{array}$ & $8 \mathrm{q} 21.3$ \\
\hline$P A L B 2$ & Partner and localizer of BRCA & Critical role in HR repair by recruiting BRCA2 and RAD51. & $16 \mathrm{p} 12.1$ \\
\hline PTEN & Phosphatase and tensin homolog & $\begin{array}{l}\text { Tumor suppressor protein. Active in DNA repair through in- } \\
\text { teractions with the Chk1 and the P53 pathways. Regulator of } \\
\text { the RAD51 activity. }\end{array}$ & $10 \mathrm{q} 23.3$ \\
\hline RAD50 & RAD50 homolog Sacharomyces cerevisiae & Protein involved in DSB repair, required for NHEJ and HR. & $5 q 23-q 31$ \\
\hline RAP80 & Ubiquitin Interaction Motif Containing 1 & $\begin{array}{l}\text { Recognize ubiquitinated } \mathrm{H} 2 \mathrm{~A} \text { and } \mathrm{H} 2 \mathrm{AX} \text { histones and re- } \\
\text { cruits the BRCA1/BARD1 heterodimer at DSB. }\end{array}$ & $5 \mathrm{q} 35.2$ \\
\hline
\end{tabular}


Table 1 - cont.

\begin{tabular}{|c|c|c|c|}
\hline Gene & Name & Function & $\begin{array}{l}\text { Cromosomal } \\
\text { location }\end{array}$ \\
\hline$R B 1$ & Retinoblastoma & Tumor suppressor protein, mediates cell cycle arrest. & $17 \mathrm{q} 22.2$ \\
\hline Rifl & RAP1 interacting factor homolog (yeast) & $\begin{array}{l}\text { Required for cell cycle arrest at S-phase in response to DNA } \\
\text { damage. }\end{array}$ & $2 q 23.3$ \\
\hline$R N F 168$ & RING Finger Protein & $\begin{array}{l}\text { E3 ubiquitin-protein ligase required for recruiting repair pro- } \\
\text { teins to DNA damage sites. }\end{array}$ & $3 q 29$ \\
\hline$T G F \beta 1$ & Transforming growth factor $\beta 1$ & $\begin{array}{l}\text { Multifunctional peptides that regulate cell proliferation, mi- } \\
\text { gration, adhesion, differentiation, and other functions. }\end{array}$ & $19 \mathrm{q} 13.1$ \\
\hline TopBP1 & Topoisomerase (DNA) II Binding Protein & S-phase checkpoint regulator. & $3 q 22.1$ \\
\hline$T O X 3$ & Tox high mobility group box family member 3 & Involved in alteration of chromatin structure. & $16 \mathrm{q} 12.1$ \\
\hline TP53 & Tumor protein p53 & $\begin{array}{l}\text { Tumor suppressor protein, cell cycle arrest, apoptosis, senes- } \\
\text { cence and DNA repair. }\end{array}$ & $17 \mathrm{p} 13$ \\
\hline$X R C C 4$ & X-Ray Repair Complementing Defective & Scaffold protein involved in NHEJ. & $5 q 14.2$ \\
\hline $53 B P 1$ & Tumor Protein P53 Binding Protein & Adaptor protein, chromatin reader. Promotes NHEJ. & $15 q 15.3$ \\
\hline
\end{tabular}

Non-homologous end joining (NHEJ)

Canonical NHEJ (C-NHEJ) is a conservative endjoining process, and this pathway is also essential for V(D)J recombination during $\mathrm{T}$ - and $\mathrm{B}$-cell lymphocyte development. NHEJ is not restricted to a particular phase of the cell cycle, but occurs preferentially during the $\mathrm{G}_{0}, \mathrm{G}_{1}$ and the early S phases (Chistiakov et al., 2008; Deckbar et al., 2011; Malu et al., 2012a,b). NHEJ involves ligation of break DNA ends and does not require sequence homology. The first step in the process is the recognition of the DNA ends by the KU heterodimer composed by the KU70 and KU80 proteins. The heterodimer binds to DNA ends and protects them from further degradation (Williams et al., 2014). Crystallographic studies of the KU70/80 heterodimer showed that it adopts a ring-shaped structure encircling the duplex DNA helix which reaches the DNA ends (Walker et al., 2001). The KU subunits are similar in domain organization; they have an amino-terminal von Willebrand domain participating in the KU heterodimerization (Fell and Schild-Poulter, 2012). The KU70/80 heterodimer forms a scaffold at the DNA ends and recruits and activates the DNA-dependent protein kinase catalytic subunit (DNA-PKcs). DNA-PKcs form a pincer-shaped structure which creates a central channel mediating the ability of DNA-PKes to bind double strand DNA (Sibanda et al., 2010; Davis et al., 2014). Subsequently, the X-ray repair complementing defective repair protein in Chinese hamster cells 4 (XRCC4) interacts with the KU70 subunit and another critical NHEJ scaffolding protein, enabling enzymes to interact with the DSB region. DNA ligase IV directly interacts with the KU heterodimer, an interaction mediated by the tandem BRCA1 C-terminal (BRCT) domains found in the C-terminus of DNA ligase IV (Ochi et al., 2014). Next, the PNKP (polynucleotide kinase-phosphatase) in- teracts with phosphorylated XRCC4. Structural analysis showed that this scaffold forms filaments interacting with the DNA ends and forms a bridge which stabilizes the ends of the DSB (Hammel et al., 2010; Ochi et al., 2014). It has also been shown that XRCC4 joins to unphosphorylated PNKP, but with less affinity. Other proteins, such as aprataxin, aprataxin and PNKP like factor (APLF), and XRCC4-like factor (XLF) also bind XRCC4.

Usually, DSB ends are irregular and show other defects, like abasic strand segments that must be solved before NHEJ occurs. If phosphate or adenylate groups are present at the DSB ends, DNA end processing may be required for subsequent ligation. PNKP is a kinase/phosphatase responsible for adding phosphate to the $5{ }^{\circ} \mathrm{OH}$ end and remove the phosphate groups at the 3 ' end (Bernstein et al., 2005). Aprataxin is a nucleotide hydrolase and transferase which catalyzes the removal of adenylate groups covalently linked to 5' phosphate termini (Grundy et al., 2013). When DSB asymmetries must be fixed, the exonuclease Artemis is phosphorylated and binds to DNAPKcs to trim redundant ends. KU has 5'deoxyribose-5phosphate (5'-dRP)/AP lyase activity involved in cleaving redundant abasic single strands present at DSB ends (Roberts et al., 2010). The Werner syndrome Rec Q helicase like protein (WRN) joins the KU heterodimer and XRCC4 and stimulate an exonuclease 3' to 5' activity (Gu et al., 2010; Malu et al., 2012). Sometimes filling of gaps in the strands at the DSB site is required, and this function may be accomplished by the $\mathrm{X}$ family polymerases ( $\mu$ and $\lambda$ polymerases) (Capp et al., 2006, 2007).

When DSB ends of two DNA segments are clean and compatible they are ligated by DNA ligase IV (Jahan et al., 2014). Ligase IV activity is stimulated by XRCC4 (Gu et $a l ., 2007)$. Incompatible ends may be joined by an interaction between ligase IV and XLF. 
There is also an alternative NHEJ pathway (A-NHEJ) which is independent of the KU70/KU80 heterodimer activity. In this mechanism, DNA ends are excised by the meiotic recombination 11 protein (MRE11) and the retinoblastoma binding protein 8 (RBBP8, synonymous of CtIP) exonucleases (Gu et al., 2010, Hammel et al., 2010), exposing microhomology regions which can be aligned, allowing the filling of the empty segments by the $\mathrm{X}$ family polymerases. Thereafter, XRCC1 and ligase III may complete the end-joining process (Frit et al., 2014). C-NHEJ is a more conservative end-joining process, but its efficacy may be affected by the highly error-prone activity of the A-NHEJ pathway, the adaptability of the C-NHEJ to repair irregular ends, and the incompatibility of some DNA ends (Bétermier et al., 2014).

\section{Homologous recombination (HR)}

HR for DSB repair requires a homologous DNA sequence provided by the sister homologous chromatid to restore a DSB lesion. Therefore, this process is only active during the $\mathrm{S}$ and $\mathrm{G} 2$ cell-cycle phases, where this sister chromatid is available as a template (Krejci et al., 2012). HR starts with the binding of the MRN complex to the DSB ends. The MRN complex is constituted by the MRE11 protein, the rad 50 homolog S. cerevisiae protein (RAD50) and the nibrin protein (NBS1) (Richard et al., 2011a,b). Then, the 3 'ends of the DSB are digested by the exonuclease activity of the MRE11/CtIP to generate free ends at the DSB that are extended by the EXO1 3'- 5' exonuclease activity (Limbo et al., 2007). Subsequently, the single-strand DNA binding protein 1 (hSSB1) binds to the free 3 ' ends and joins the replication protein A (RPA) to protect these free ends from further degradation, to prevent inappropriate annealing that could lead to genomic rearrangements and to prevent hairpin formation (Chen et al., 2013). RPA is a heterotrimeric complex formed by RPA70, RPA32 and RPA14 also involved in the control of DNA replication and repair mechanisms (Sleeth et al., 2007). Then, RPA is replaced by an array of RAD51 proteins assembled to eight BRC domains of the breast cancer 2 (BRCA2) protein and the participation of five additional proteins (RAD51B/RAD51C/RAD51D/XRCC2/XRCC3) (West, 2003). $\operatorname{Rad} 51$ is a recombinase which forms a pre-synaptic RAD51-BRCA2 nucleoprotein filament on the DNA (Williams and Michael 2010). The RAD51-BRCA2 nucleoprotein filaments search and invade the homologues sequences to form a Holliday junction structure (Masson et al., 2001). The sister chromatids are joined by the cohesin proteins $\mathrm{SMC1}, 3,5$ and 6 . These proteins facilitate the cohesion of the DSB and the intact homologous strands to propitiate the homologous recombination (Kim et al., 2002, Kong et al., 2014). After the invasion of the sister chromatid (synapses) and the alignment of homologous DNA sequences, RAD51 is removed leaving a free 3'-OH end enabling the repairing DNA synthesis by the DNA poly- merase $\delta$ in the $3^{\prime}-5$ ' direction with the help of resolvases, like the structure-specific endonuclease subunit (MUS81), the essential meiotic structure-specific endonuclease 1 (EME1), and the Holliday junction 5' flap endonuclease (GEN1) (Constantinou et al., 2002). Once the synthesis of the repaired DNA is completed, these enzymes resolve the Holliday junction and the DNA ends are joined by the DNA ligase I (Matos and West 2014). Although not completely understood, the BRCA1 protein plays an important role in directing the scaffolding of the Rad51-BRCA2 filaments and also interacts with the histone $\mathrm{H} 2 \mathrm{AX}$ (described below) during HR repair (O'Donovan and Livingston, 2010).

The HR repair method is considered error-free, because it uses the homologous sequence of the sister chromatid as a template for synthesis. It has been proposed that chromosome condensation makes it difficult to search for homologous sequences in the nucleus, and therefore NHEJ is more frequently employed by cells to repair DSB (Deckbar et al., 2011; Langerak and Russell, 2011). The high fidelity of HR is also proposed to explain the low sensitivity and cellular resistance of cells in S/G2 phase to ionizing radiation. Therefore it is suggested that resistance to radiotherapy is mediates by HR (Somaiah et al., 2013).

\section{Single-strand alignment (SSA)}

SSA can be regarded as a special form of HR repair. This repair mechanism is not conservative and is dependent on the presence of repeated sequences flanking the DSB. It begins with the cleavage of the 5 '-end of one strand of DNA to expose microhomologies. This is mediated by a protein complex composed of the CtIP and the MRN complex, followed by the alignment of the homologous ends. Nonaligned regions are removed by the ERCC1/XPF nucleases (resulting in a loss of nucleotides in the DNA chain) and then, the DNA ends are joined by the DNA ligase III (Salles et al., 2011; Liu et al., 2014). Evidence suggests that SSA repair can elicit the formation of the pathological chromosome translocations related with cancer (Manthey and Bailis, 2010).

\section{Radiosensitivity in Breast Cancer Patients}

Radiosensitivity is the susceptibility of the cells or tissues to ionizing radiation. Some patients may be more sensitive to radiation. Sensitivity results from the toxic effects of radiotherapy resulting in lesions of the patient's normal tissues. These effects may be acute or late, depending on the time of their manifestation. Acute effects occur during the treatment or shortly after and they are usually reversible and occur in rapidly proliferating tissues, like skin, gastrointestinal tract and hematopoietic tissues. Late effects manifest six months or later after the treatment. Late effects can be permanent, mainly affecting slowly proliferating tissues such as kidneys, heart, and the nervous system, and may involve systemic deregulations of the endocrine system (Barnett et al., 2009). Radiation promotes DSB as 
mentioned above, and this damage is detrimental for genome integrity (Chistiakov et al., 2008; Rübe et al., 2008; Henríquez-Hernández et al., 2011).

Mechanisms of hypersensitivity to ionizing radiation are still unclear, but is estimated that $70 \%$ of hypersensitivity cases are due to genetic variants (Turesson et al., 1996). As mentioned above, mutations in the $A T M$ gene are associated with extreme hypersensitivity to ionizing radiation (Masuda and Kamiya, 2012), and polymorphisms in genes like $X R C C 3$ and $R A D 51$ increase the risk of radiosensitivity (Vral et al., 2011). These genes are also implicated in breast cancer. Mayer et al. (2011) analyzed gene expression in peripheral blood lymphocytes of breast and cervical cancer patients. They identified 153 genes altered by ionizing radiation. These genes are involved in cell cycle control and apoptosis in response to radiation. Of these, 67 genes were useful to discriminate between normal reacting patients and subjects with severe radiosensitivity. However, the analyses were performed on lymphocytes, and the authors comment that an analysis of expression in different tissues would be required to define a more precise gene signature (Mayer et al., 2011).

The 7,8-dihydro-8-oxo-2'-deoxyguanosine (8-oxo$\mathrm{dG})$ base damage is produced by ionizing radiation and is repaired by nucleotide excision followed by removal of this abnormal deoxynucleoside out of the cell (Evans et al., 2010). 8-oxo-dG has been used as a urinary marker of oxidative stress and has been associated with lung cancer (Il'yasova et al., 2012) and gastrointestinal diseases (Ock et al., 2012). It has also been proposed as a marker for radiosensitivity (Erhola et al., 1997, Roszkowski and Olinski, 2012). Haghdoost et al. (2001) studied 8-oxo-dG urinary levels in breast cancer patients before and after adjuvant radiotherapy (4 to 6 Gy). Radiosensitive patients showed skin redness in the radiated areas and significantly increased urinary levels of 8-oxo-dG, and these authors proposed the use of this deoxynucleoside as a urinary biomarker for radiosensitivity. This biomarker facilitates the study of individual radiosensitivity, since the abnormal metabolite maybe measured by ELISA (Haghdoost et al., 2001). In a study by Skiöld et al. (2013), radiation-induced oxidative stress response was analyzed by the 8-oxo-dG biomarker in serum from ex-vivo irradiated leukocytes samples obtained from breast cancer patients that developed severe acute skin reactions (RTOG [Radiotherapy Oncology Group Criteria] grade 3-4) during radiotherapy and from patients with breast cancer showing no early skin reactions after radiotherapy (RTOG grade 0). The authors demonstrated that patients with RTGO grade 0 showed increased extracellular serum levels of 8-oxo-dG, in contrast with the significantly low serum levels observed in patients with RTOG grades 3 and 4 , indicating that 8 -oxo-dG is a useful biomarker to analyze cellular responses to ionizing radiation (Skiöld et al., 2013). Nonetheless, 8-oxo-dG can also result from cell exposure to oxidative stress by ROS, as may occur when tis- sues are exposed to environmental pollutants (Hecht, 1999). For these reasons this biomarker is not specific for ionizing radiation but, as in the case of the studies by Skiöld et al. (2013), it is helpful as a comparative ex vivo test of irradiated cells to define the biological effects of ionizing radiation. Extracellular levels of 8-oxo-dG are appropriate indicators of the cells capability to repair the DNA damage caused by ROS.

Certain phenotypes of breast cancer have been associated with locoregional recurrence (LRR). Brollo et al. (2013) suggested that HER2 + tumors are more susceptible to ionizing radiation, while Voduc et al. (2010) observed that LRR seemed higher in patients with triple negative marker breast cancer, although the number of LRR events was small. At present, there are no molecular methods to discriminate between patients with high and low LRR (Britten et al., 2013). In addition, there is not enough information regarding the possible adverse effects of radiotherapy that may induce genomic and epigenetic modifications and changes in gene-expression profiles in breast cancer.

Henríquez-Hernández et al. (2011) analyzed isolated peripheral blood lymphocytes (PBLs) from patients with advanced breast cancer treated ex vivo with high radiotherapy doses to study ionizing radiation resistance. They showed that lymphocytes from patients with low DNA damage and high apoptosis rates had low risks of radiation adverse events.

Studies analyzing the type of repair that occurs when cells are exposed to radiation and the correlation with abnormal expression of certain genes involved in DSB repair have also been conducted. In vitro studies of Bca11 (familial breast cancer cell line) and Bca10 (sporadic breast cancer cell line) cell lines showed high NHEJ repair activity and direct HR non-conservative repair in the Bcall cell line. The Bca10 cell line also showed an increase in nonconservative repair of direct HR, but to a lesser degree than Bca11. Consequently, repair mechanisms in these cell lines may cause deletions in the DNA sequence and cell cycle deregulation (Keimling et al., 2008). These authors performed a study in PBLs from patients with sporadic breast cancer, healthy women with familial risk of breast cancer, and healthy controls, and they demonstrated increased NHEJ and SSA in both, cancer patients and subjects at hereditary risk, $v s$. the healthy controls. This study suggested that these two groups are prone to extended nonconservative DSB repairing mechanisms. Based on these results, Keimling et al. (2012) implemented a test to analyze DSB repair in vitro.

\section{Techniques for DSB Repair Analysis}

Some tests have been devised to assess DNA damage in response to diverse substances, microorganisms, or environmental conditions. Some of these tests are described below. 


\section{Comet assay}

The alkaline comet assay involves measurement of DNA damage in SSB and DSB. This method is fast and cheap. It provides important information about the risk of diseases related to oxidative stress (Alapetite et al., 1999; Dusinska and Collins, 2008). In this assay, cells are embedded in a thin layer of agarose on a thin glass slide, cells are lysed in a solution containing detergent and $\mathrm{NaCl}$, releasing the DNA from the proteins bound to it, but leaving DNA fragments still attached to the nuclear membrane. Then, the plate is incubated in an alkaline solution, an electrophoresis is run and DNA is stained with ethidium bromide. DNA fragments travel to the anode forming a comet-like image when viewed by fluorescence microscopy (Fikrová et al., 2011, Baumgartner et al., 2012). The image of the comet head denotes the DNA content and the tail the frequency of DNA breaks (Figure 2B). Software programs designed to analyze the comet image allow measurement of DNA content and tail length. The length of the comet tail correlates with the level of DNA damage.

Hair et al. (2010) used a modified comet assay method in which slides with cells embedded in agarose were incubated with three different treatments: 1) alkaline electrophoresis to detect SSB induced radiation and alkaline-labile sites; 2) electrophoresis of cells treated with formamidopyrimidine [Fapy] -DNA glycosylase (Fpg);

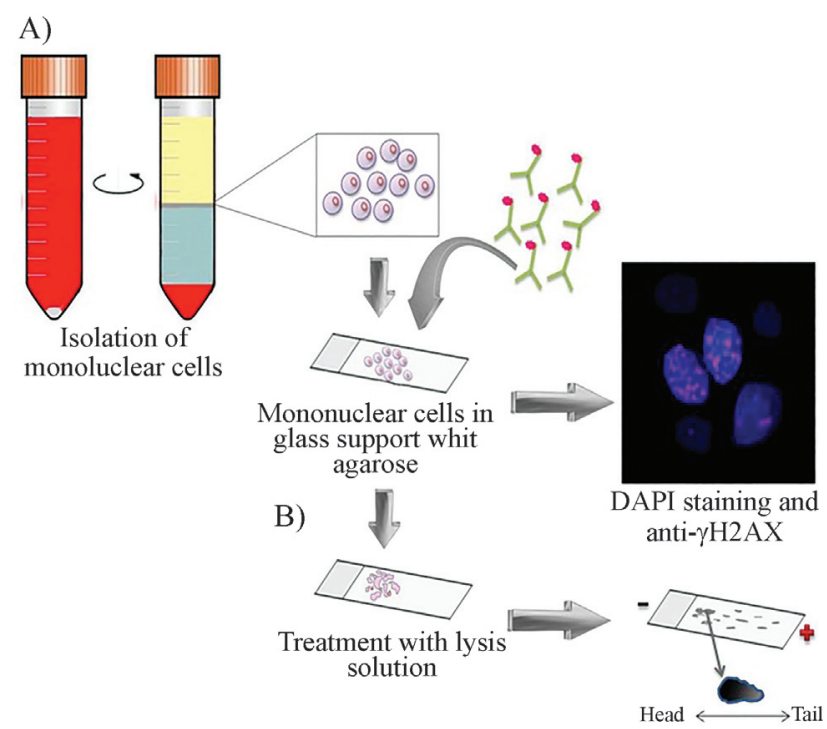

Figure 2 - General assays for detecting DNA damage (A) Immunohistochemistry with antibodies directed against $\gamma-\mathrm{H} 2 \mathrm{AX}$ : peripheral blood mononuclear cells are isolated, nuclei are stained with DAPI and with antibodies directed at $\gamma$-stained H2AX and visualized under fluorescent microscopy. (B) Comet assay: the comet assay is also performed on mononuclear cells. The cells are embedded in agarose on a thin glass slide, cells are lysed and incubated in an alkaline solution. Subsequently, DNA fragments are separated by electrophoresis and stained with ethidium bromide. The comet-like image is viewed under a fluorescence microscope. The length of the comet tail indicates the frequency of DNA breaks this releases the damaged purines, leaving apurinic sites (AP sites) that are subsequently cleaved with the cellular AP lyase, producing single strand fragments which can be visualized in the comet assay, and 3) electrophoresis after treatment of the cells with bacterial endonuclease EndoIII, which cleaves the damage strands at sites presenting oxidized pyrimidines, thus increasing the sensitivity of the comet assay by leaving gaps in mutated bases (Hair et al., 2010).

Some disadvantages of the comet assay are the variability between different protocols and between laboratories, which makes it difficult to define ionizing radiation toxicities, so this issue will require adoption of standardized and comparable protocols (Forchhammer et al., 2010; Henríquez-Hernández et al., 2012; Azqueta et al., 2014). Sirota et al. (2014) studied inter-laboratory variation of comet assay factors, like slide brands, duration of alkali treatment and electrophoresis conditions, and they found that laboratory differences were associated with electrophoresis conditions, especially the temperature during alkaline electrophoresis, which affects the rate of conversion of alkali labile sites to single stranded breaks (Sirota et al., 2014). Additionally, it has been suggested that implementation of a standard software will be required for comet assay interpretation (Fikrová et al., 2011).

\section{$\gamma-\mathrm{H} 2 \mathrm{AX}$}

The histone $\mathrm{H} 2 \mathrm{AX}$ variant of the histone $\mathrm{H} 2 \mathrm{~A}$ is present in subsets of nucleosomes ( 2 to $25 \%$ of the total H2A) and has been implicated in DSB repair. When H2AX is phosphorylated at the serine residue 139 by phosphoinositide-3-kinase-related protein kinases (PIKKs), the phosphate group adopts a $\gamma$ position in the protein, constituting the gamma $\mathrm{H} 2 \mathrm{AX}(\gamma-\mathrm{H} 2 \mathrm{AX})$ configuration (Rogakou et al., 1998; Rothkamm and Horn, 2009). This phosphoprotein acts in early events of DNA repair by decondensing the chromatin near the DSB (Kruhlak et al., 2006). Additionally, $\gamma \mathrm{H} 2 \mathrm{AX}$ joins to the DSB ends forming a " $\gamma \mathrm{H} 2 \mathrm{AX}$ focus" which is extended for several $\mathrm{Mb}$ at the sides of the DSB. A method used for the analysis of DNA damage is the measurement of $\gamma$-H2AX using antibodies against

In the $\gamma-\mathrm{H} 2 \mathrm{AX}$ assays, peripheral blood is collected and mononuclear cells are separated and fixed on a glass surface. Then, an immunohistochemistry with anti- $\gamma-$ $\mathrm{H} 2 \mathrm{AX}$ antibody is performed and the results are analyzed by fluorescence microscopy in which fluorescent foci are measured (Figure 2A). This test may be also analyzed by flow cytometry or by western blot (Kinner et al., 2008; Dickey et al., 2009; Podhorecka et al., 2010).

$\gamma-\mathrm{H} 2 \mathrm{AX}$ foci measurements in patients before and after radiotherapies using low and high doses of ionizing radiation have shown a linear relationship between DNA damage and exposure to radiation. The initial number of $\gamma$-H2AX foci is consistent with DSBs in the cells. After a 
while, the $\gamma-\mathrm{H} 2 \mathrm{AX}$ foci disappear due to the DNA repair (Rübe et al., 2008; Horn et al., 2011). This method is sensitive for measuring DNA repair in patients undergoing radiotherapy, but it is also applied in other fields, such as DNA damage analysis due to occupational exposure or contact with environmental pollutants, cigarette smoke, drugs, etc.. It is important to note that these co-exposures may affect the results in radiotherapy patients and, hence, should be considered on an individual basis. Furthermore, phosphorylation of H2AX is observed in the absence of DSB in the replication process, in mitosis and during DNA fragmentation in apoptosis. Therefore, the test must be able to distinguish between apoptotic and non-apoptotic cells (Dickey et al., 2009).

Comet assay and $\gamma-\mathrm{H} 2 \mathrm{AX}$ methods described above help to assess DNA damage and repair, but do not allow discrimination of the type of damage, like SSB or DSB. It is also important to analyze whether the damage is repaired and what kind of repair mechanism is operating to assess whether cells are sensitive or resistant to ionizing radiation.

\section{Engineered proteins to detect spontaneous DSB}

Shee et al. (2013) developed a new synthetic technology to quantify DSBs in bacterial and mammalian cells. This method use the green fluorescent-protein (GFP) fused to the GAM protein (GAM-GFP), a viral protein from bacteriophage $\mathrm{Mu}$, which shares sequence homology with the eukaryotic proteins KU80 and KU70 involved in NHEJ (Aparicio et al., 2014). Unlike the KU protein, the GAM protein is not involved in DNA repair reactions. GAM binds to DNA and inhibits a variety of exonucleases involved in DNA repair (Abraham and Symonds, 1990; Fagagna et al., 2003; Shee et al., 2013). This advance allows the study and quantification of DNA breaks. In this method, the I-SceI endonuclease is used to make site specific DSBs and cells are transfected with a Mu GAM-GFP fusion expression vector. The GAM-GFP protein joins the DSBs formed by the I-SceI treatment, generating fluorescence at the damaged sites which can be analyzed by fluorescence microscopy. Since the GAM-GFP protein competes with KU proteins, this results in low levels of
A)

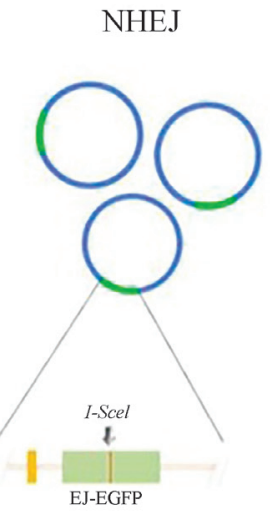

SSA

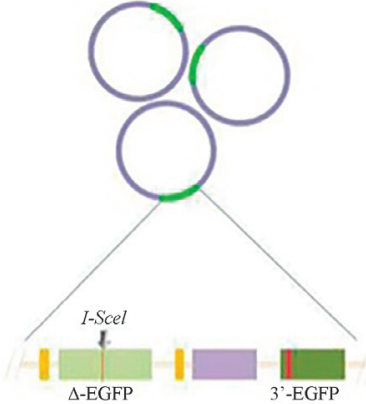

HR

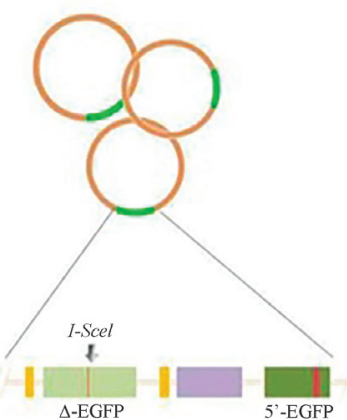

B)

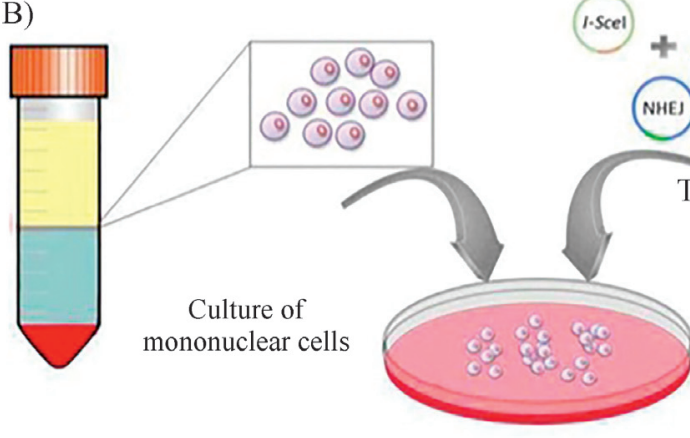

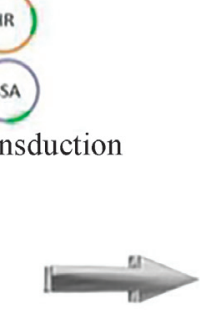

Incubation

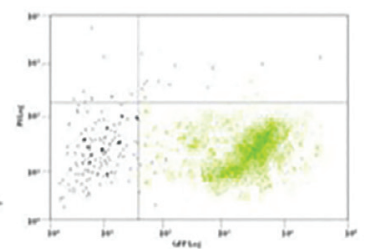

Flow cytometry analysis

Figure 3 - Specific assays for detecting DNA damage (A) The EJ-EGFP plasmids contains a mutated version of the EGFP gene (green light bar) created by inserting a restriction site for the meganuclease I-SceI flanked by a $5 \mathrm{bp}$ microhomology sites (black arrows); this plasmid was designed to be repaired by NHEJ. The $\Delta$-EGFP/3'EGFP and $\Delta$-EGFP/5'EGFP plasmids contain an array of an EGFP mutated gene containing an I-SceI site (green light bar) followed by a spacer (purple bar) and EGFP gene versions truncated at their flanking 3' and 5' ends, respectively (dark green bars) which allow the reconstitution of the wild-type version of the marker gene by SSA and HR, respectively. (B) Analysis of DSB repair: The assay is performed in three cultures of peripheral blood lymphocytes (PBLs), transduced separately with each of the plasmid versions designed for discrimination of SSA, NHEJ and HR. The cultures are co-transduced with an additional plasmid expressing the I-SceI enzyme. After generating DBS in the target plasmids by the expressed restriction enzyme, DNA repair in PBLs repair by each of the different DNA repair pathway may be monitored by restoration of the wild-type version of EGFP $24 \mathrm{~h}$ after transduction by measuring EGFP florescence by flow cytometry. 
DNA damage, thus limiting this technology to the study of DSB repair by HR (Shee et al., 2013).

\section{Identification of repair mechanisms by specific DNA substrates}

As mentioned above, Keimling et al. (2012) developed an in vitro method in which PBLs are transfected with marker plasmids for enabling discrimination of the mechanisms involved in DSB repair: HR, NHEJ, and SSA (Figure $3 A)$. In this procedure, PBLs are transduced in three different experiments with separate plasmids, each containing the EGFP reporter gene followedby different sequences amenable to undergo one of the different mechanisms of DNA repair defined above. Cells in the three groups are co-transduced with a plasmid codifying for I-SceI as the inductor of DSB repair events. Fluorescence detection after $24 \mathrm{~h}$ by flow cytometry in any of the three transduced cells of the panel measures the events of each individual operating mechanism, allowing more detailed information about DSB repair in individual patients (Figure 3B). This test is amenable for high-throughput sample processing and analysis (Boehden et al., 2002; Keimling et al., 2012).

\section{Conclusions}

Detection of genetic alterations in genes associated with breast cancer, particularly genes related to DSB repair, may allow the diagnosis for genetic patients with breast cancer, but current methods based on genomic methodologies to detect mutations are expensive and not suitable for screening subjects under risk for increased DSB events. Almost $20 \%$ of the breast cancer patients will show acute complications due to radiotherapy. Hence, evaluation of DSB repair is a useful tool for assessing breast cancer risk and predicting the response and complications associated with conventional radiotherapy. Methods for studying DSB repair in PBLs are less expensive and suitable for designing high-throughput analyses for screening subjects at high risk for cancer in general, to anticipate adverse events and to offer individualized therapies. These methods will be relevant for preventing unnecessary radiation exposure, for screening of patients which will not benefit from radiotherapy, and for adjusting radiotherapy regimes in patients requiring this therapeutic option, in order to avoid adverse effects associated with DSB in tissues that can ameliorate a patient's prognosis.

A general comparison of methods shows that the comet assay assesses the amount of DNA damage, is inexpensive and is easy to perform in conventional laboratories. However it does not provide detailed information about the DNA lesion (SSB or DSB) and neither the DSB repair mechanism (NHEJ, SSA or HR). Another disadvantage of this method is the inter-protocol and the inter-laboratory variability in results. Nonetheless, this test is useful as a preliminary tool for assessing DNA damage. Detection of
$\gamma-\mathrm{H} 2 \mathrm{AX}$ is also a simple procedure and measurement of $\gamma$-H2AX may be performed by fluorescent microscopy, but the technique is also amenable for flow cytometry or western blot assays, which may render a more precise quantification than the comet assay. However, the detection of $\gamma$-H2AX does not discriminate between SSB and DSB. Furthermore, $\gamma$-H2AX may be phosphorylated during mitosis or apoptosis, resulting in false positives. The method developed by Shee et al. (2013) is more sensitive for DSB detection. It uses the GAM protein linked to EGFP, which joins the ends of the DSB and prevents DNA repair. Cells with DSB may be measured by fluorescent microscopy or flow cytometry. This technique requires molecular and cell biology techniques which may constitute an obstacle for diagnostic laboratories. The method developed by Keimling et al. (2012) enables the discrimination and measurement of the type of DSB repair mechanism. This method also uses techniques of molecular and cell biology, which may complicate its implementation in diagnostic laboratories, but this refined technology may have a great impact in defining a patient's risk to DSB induced by ionizing radiation.

Further advances in the discovery of genes involved in DNA repair and additional factors affecting genome stability will prompt the implementation of better technologies to study DNA damage in the clinical setting so as to avoid radiation-related toxicities.

\section{Acknowledgments}

This work received sponsorship from the PAICYTUANL CS943-11 call for research.

\section{References}

Abraham ZH and Symonds N (1990) Purification of overexpressed gam gene protein from bacteriophage $\mathrm{Mu}$ by denaturation-renaturation techniques and a study of its DNAbinding properties. Biochem J 269:679-684.

Alapetite C, Thirion P, De la Rochefordie A, Cosset JM and Moustacchi E (1999) Analysis by alkaline comet assay of cancer patients with severe reactions to radiotherapy: Defective rejoining of radioinduced dna strand breaks in lymphocytes of breast cancer patients. Int J Cancer 90:83-90.

Aparicio T, Baer R and Gautier J (2014) DNA double-strand break repair pathway choice and cancer. DNA Repair 19:169-175.

Azqueta A, Slyskova J, Langie SAS, Gaivão ION and Collins A (2014) Comet assay to measure DNA repair: Approach and applications. Front Genet 5:1-8.

Barnett GC, West CML, Dunning AM, Elliott RM, Coles CE, Pharoah PDP and Burnet NG (2009) Normal tissue reactions to radiotherapy: Towards tailoring treatment dose by genotype. Nat Rev Cancer 9:134-142.

Baumgartner A, Kurzawa-Zegota M, Laubenthal J, Cemeli E and Anderson D (2012) Comet-assay parameters as rapid biomarkers of exposure to dietary/environmental compounds an in vitro feasibility study on spermatozoa and lymphocytes. Mutat Res 743:25-35. 
Bernstein NK, Williams RS, Rakovszky ML, Cui D, Green R, Karimi-Busheri F, Mani RS, Galicia S, Koch CA, Cass CE, et al. (2005) The molecular architecture of the mammalian DNA repair enzyme, polynucleotide kinase. Mol Cell 17:657-670.

Bétermier M, Bertrand P and Lopez BS (2014) Is non-homologous end-joining really an inherently error-prone process PLoS Genet 10:e1004086.

Boehden GS, Su S, Rimek A, Preuss U, Scheidtmann K and Wiesmu L (2002) DNA substrate dependence of p53-mediated regulation of double-strand break repair. Mol Cell Biol 22:6306-06317.

Bosviel R, Garcia S, Lavediaux G, Michard E, Dravers M, Kwiatkowski F, Bignon Y and Bernard-Gallon DJ (2012) BRCA1 promoter methylation in peripheral blood DNA was identified in sporadic breast cancer and controls. Cancer Epidemiol 36:177-182.

Britten A, Rossier C, Taright N, Ezra P and Bourgier C (2013) Genomic classifications and radiotherapy for breast cancer. Eur J Pharmacol 717:67-70.

Brollo J, Kneubil MC, Botteri E, Rotmensz N, Duso BA, Fumagalli L, Locatelli MA, Criscitiello C, Lohsiriwat V, Goldhirsch A, et al. (2013) Locoregional recurrence in patients with HER2 positive breast cancer. Breast 22:856-862.

Brown LC, Mutter RW and Halyard MY (2015) Benefits, risks, and safety of external beam radiation therapy for breast cáncer. Int J Womens Health 7:449-458.

Capp JP, Boudsocq F, Bertrand P, Laroche-Clary A, Pourquier P, Lopez BS, Cazaux C, Hoffmann JS and Canitrot Y (2006) The DNA polymerase $\lambda$ is required for the repair of noncompatible DNA double strand breaks by NHEJ in mammalian cells. Nucleic Acids Res 34:2998-3007.

Capp JP, Boudsocq F, Besnard AG, Lopez BS, Cazaux C, Hoffmann JS and Canitrot Y (2007) Involvement of DNA polymerase $\mu$ in the repair of a specific subset of DNA double-strand breaks in mammalian cells. Nucleic Acids Res 35:3551-3560.

Chen H, Lisby M and Symington L (2013) RPA coordinates DNA end resection and prevents formation of DNA hairpins. Mol Cell 50:589-600.

Chistiakov DA, Voronova NV and Chistiakov PA (2008) Genetic variations in DNA repair genes, radiosensitivity to cancer and susceptibility to acute tissue reactions in radiotherapytreated cancer patients. Acta Oncol 47:809-824.

Constantinou A, Chen XB, McGowan CH and West SC (2002) Holliday junction resolution in human cells: Two junction endonucleases with distinct substrate specificities. EMBO J 21:5577-5585.

Davis AJ, Chen BPC and Chen DJ (2014) DNA-PK: A dynamic enzyme in a versatile DSB repair pathway. DNA Repair 17:21-29.

Deckbar D, Jeggo PA and Löbrich M (2011) Understanding the limitations of radiation-induced cell cycle checkpoints. Crit Rev Biochem Mol Biol 46:271-283.

Delaney G, Jacob S, Featherstone C and Barton M (2005) The role of radiotherapy in cancer treatment estimating optimal utilization from a review of evidence-based clinical guidelines. Cancer 104:1129-1137.

Dickey JS, Redon CE, Nakamura AJ, Baird BJ, Sedelnikova OA and Bonner WM (2009) H2AX: Functional roles and potential applications. Chromosoma 118:683-92.
Dusinska M and Collins AR (2008) The comet assay in human biomonitoring: Gene-environment interactions. Mutagenesis 23:191-205.

Do TA, Brooks JT, Le Neveu MK and La Rocque JR (2014) Double-strand break repair assays determine pathway choice and structure of gene conversion events in Drosophila melanogaster. G3 4:425-432.

Dunne-Daly CF (1999) Principles of radiotherapy. Br J Hosp Med (Lond) 74:C166-C169.

Erhola M, Toyokuni S, Okada K, Tanaka T, Hiai H, Ochi H, Uchida K, Osawa T, Nieminen MM, Alho H, et al. (1997) Biomarker evidence of DNA oxidation in lung cancer patients: Association of urinary 8-hydroxy-2'-deoxyguanosine excretion with radiotherapy, chemotherapy, and response to treatment. FEBS Lett 409:287-291.

Evans MD, Saparbaev M and Cooke MS (2010) DNA repair and the origins of urinary oxidized 2'- deoxyribonucleosides. Mutagenesis 25:433-442.

Fagagna FA, Weller GR, Doherty AJ and Jackson SP (2003) The Gam protein of bacteriophage $\mathrm{Mu}$ is an orthologue of eukaryotic Ku. EMBO Rep 4:47-52.

Fell VL and Schild-Poulter C (2012) Ku regulates signaling to DNA damage response pathways through the $\mathrm{Ku} 70$ von Willebrand a domain. Mol Cell Biol 32:76-87.

Fikrová P, Stetina R, Hronek M, Hyspler R, Tichá A and Zadák Z (2011) Application of the comet assay method in clinical studies. Wien Klin Wochenschr 123:693-699.

Forchhammer L, Johansson C, Loft S, Godschalk RWL, Sabine A, Langie S, Jones GDD, Kwok RWL, Collins AR, Azqueta A, et al. (2010) Variation in the measurement of DNA damage by comet assay measured by the ECVAG y inter-laboratory validation trial. Mutagenesis 25:113-123.

Frit P, Barboule N and Yuan Y (2014) Alternative end-joining pathway(s): Bricolage at DNA breaks. DNA Repair 17:8197.

Grundy GJ, Rulten SL, Zeng Z, Arribas-Bosacoma R, Iles N, Manley K, Oliver A and Caldecott KW (2013) APLF promotes the assembly and activity of non-homologous end joining protein complexes. EMBO J 32:112-25.

Gu J, Lu H, Tippin B, Shimazaki N, Goodman MF and Lieber MR (2007) XRCC4:DNA ligase IV can ligate incompatible DNA ends and can ligate across gaps. EMBO J 26:10101023.

Gu J, Li S, Zhang X, Wang LC, Niewolik D, Schwarz K, Legerski RJ, Zandi E and Lieber MR (2010) DNA-PKcs regulates a single-stranded DNA endonuclease activity of Artemis. DNA Repair 9:429-437.

Guo G-S, Zhang F-M, Gao R-J, Delsite R, Feng Z-H and Powell SN (2011) DNA repair and synthetic lethality. Int J Oral Sci 3:176-179.

Hair JM, Terzoudi GI, Hatzi VI, Lehockey KA, Srivastava D, Wang W, Pantelias GE and Georgakilas AG (2010) BRCA1 role in the mitigation of radiotoxicity and chromosomal instability through repair of clustered DNA lesions. Chem Biol Interact 188:350-358.

Hammel M, Yu Y, Fang S, Lees-Miller SP and Tainer JA (2010) XLF regulates filament architecture of the XRCC4.Ligase IV complex. Structure 18:1431-1442.

Haghdoost S, Svoboda P and Ingemar N (2001) Can 8-oxo-dg be used as a predictor for individual radiosensitivity? Int $\mathrm{J}$ Radiat Oncol Biol Phys 50:405-410. 
Hecht SS (1999) DNA adduct formation from tobacco-specific N-nitrosamines. Mutat Res 424:127-142.

Henríquez-Hernández LA, Carmona-Vigo R, Pinar B, Bordón E, Lloret M, Núñez MI, Rodríguez-Gallego $\mathrm{C}$ and Lara PC (2011) Combined low initial DNA damage and high radiation-induced apoptosis confers clinical resistance to longterm toxicity in breast cancer patients treated with high-dose radiotherapy. Radiat Oncol 6:1-8.

Henríquez-Hernández LA, Bordón E, Pinar B, Lloret M, Rodríguez-Gallego C and Lara PC (2012) Prediction of normal tissue toxicity as part of the individualized treatment with radiotherapy in oncology patients. Surg Oncol 21:201-206.

Horn S, Barnard S and Rothkamm K (2011) Gamma-H2AXbased dose estimation for whole and partial body radiation exposure. PloS One 6:e25113.

Hornhardt S, Rößler U, Sauter W, Rosenberger A, Illig T, Bickeböller H, Wichmann H and Gomolka M (2014) Genetic factors in individual radiation sensitivity. DNA Repair 16:54-65.

Il'yasova D, Scarbrough P and Spasojevic I (2012) Urinary biomarkers of oxidative status. Clin Chim Acta 413:1446-1453.

Jahan F, Kweon J, Wang Y, Han E, Kan Y, Lichter N, Weisensel $\mathrm{N}$ and Hendrickson EA (2014) A role for XLF in DNA repair and recombination in human somatic cells. DNA Repair $15: 39-53$

Keimling M, Kaur J, Bagadi SAR, Kreienberg R, Wiesmüller L and Ralhan R (2008) A sensitive test for the detection of specific DSB repair defects in primary cells from breast cancer specimens. Int. J Cancer 123:730-6.

Keimling M, Deniz M, Varga D, Stahl A, Schrezenmeier H, Kreienberg R, Hoffmann I, König $\mathrm{J}$ and Wiesmüller L (2012) The power of DNA double-strand break (DSB) repair testing to predict breast cancer susceptibility. FASEB J 26:2094-2104.

Kim JS, Krasieva TB, LaMorte V, Malcolm A, Taylor R and Yokomori K (2002) Specific recruitment of human cohesin to laser-induced DNA damage. J Biol Chem 277:4514945153.

Kinner A, Wu W, Staudt C and Iliakis G (2008) Gamma-H2AX in recognition and signaling of DNA double-strand breaks in the context of chromatin. Nucleic Acids Res 36:5678-5694.

Knaul FM, Nigenda G, Lozano RCM, Arreola-Ornelas H, Langer A and Frenk J (2009) Cáncer de mama en México: Una prioridad apremiante. Salud Públ Mex 51:335-344.

Kong X, Ball Jr AR, Pham HX, Zeng W, Chen H, Schmiesing JA, Kim J, Berns M, Yokomori K, Ball AR, et al. (2014) Distinct functions of human Cohesin-SA1 and Cohesin-SA2 in double strand break repair. Cell Mol Biol 34:685-698.

Krejci L, Altmannova V, Spirek M and Zhao X (2012) Homologous recombination and its regulation. Nucleic Acids Res 40:5795-5818.

Kruhlak MJ, Celeste A, Dellaire G, Fernandez-Capetillo O, Müller WG, McNally JG, Bazett-Jones DP and Nussenzweig A (2006) Changes in chromatin structure and mobility in living cells at sites of DNA double-strand breaks. Int J Cell Biol 172:823-834.

Langerak P and Russell P (2011) Regulatory networks integrating cell cycle control with DNA damage checkpoints and double-strand break repair. Philos Trans R Soc Lond B Biol Sci 366:3562-3571.
Limbo O, Chahwan C, Yamada Y, Bruin RAM, Wittenberg C and Russell P (2007) Ctp1 is a cell cycle-regulated protein that functions with Mre11 complex to control double-strand break repair by homologous recombination. Mol Cell 28:134-146.

Liu C, Srihari S, Cao K-AL, Chenevix-Trench G, Simpson PT, Ragan MA and Khanna KK (2014) A fine-scale dissection of the DNA double-strand break repair machinery and its implications for breast cancer therapy. Nucleic Acids Res 42:6106-6127.

Malu S, De Ioannes P, Kozlov M, Greene M, Francis D, Hanna M, Pena J, Escalante CR, Kurosawa A, Erdjument-Bromage H, et al. (2012a) Artemis C-terminal region facilitates V(D)J recombination through its interactions with DNA Ligase IV and DNA-PKcs. J Exp Med 209:955-963.

Malu S, Malshetty V, Francis D and Cortes P (2012b) Role of non-homologous end joining in $\mathrm{V}(\mathrm{D}) \mathrm{J}$ recombination. Immunol Res 54:233-246.

Manthey GM and Bailis AM (2010) Rad51 inhibits translocation formation by non-conservative homologous recombination in Saccharomyces cerevisiae. PloS One 5:e11889.

Masson JY, Tarsounas MC, Stasiak AZ, Stasiak A, Shah R, McIlwraith MJ, Benson FE and West SC (2001) Identification and purification of two distinct complexes containing the five RAD51 paralogs. Genes Dev 8:3296-3307.

Masuda Y and Kamiya K (2012) Molecular nature of radiation injury and DNA repair disorders associated with radiosensitivity. Int J Lab Hematol 95:239-245.

Matos J and West SC (2014) Holliday junction resolution: Regulation in space and time. DNA Repair 19:176-181.

Mayer C, Popanda O, Greve B, Fritz E, Illig T, Eckardt-Schupp F, Gomolka M, Benner A and Schmezer P (2011) A radiation-induced gene expression signature as a tool to predict acute radiotherapy-induced adverse side effects. Cancer Lett 302:20-28.

Mladenov E, Magin S, Soni A and Iliakis G (2013) DNA double-strand break repair as determinant of cellular radiosensitivity to killing and target in radiation therapy. Front Oncol 3:1-18.

Ochi T, Wu Q and Blundell TL (2014) The spatial organization of non-homologous end joining: From bridging to end joining. DNA Repair 17:98-109.

Ock C, Kim E, Choi DJ, Lee HJ, Hahm K and Chung MH (2012) 8-Hydroxydeoxyguanosine: Not mere biomarker for oxidative stress, but remedy for oxidative stress-implicated gastrointestinal diseases. World J Gastroenterol 18:302-308.

O'Donovan PA and Livingston DM (2010) DM. BRCA1 and BRCA2: Breast/ovarian cancer susceptibility gene products and participant ins in double strand break repair. J Carcinog 31:961-967.

Pastink A, Eeken JCJ and Lohman PHM (2001) Genomic integrity and the repair of double-strand DNA breaks. Mutat Res 481:37-50.

Patel RR and Arthur DW (2006) The emergence of advanced brachytherapy techniques for common malignancies. Hematol Oncol Clin North Am 20:97-118.

Podhorecka M, Skladanowski A and Bozko P (2011) H2AX Phosphorylation: Its role in DNA damage response and cancer therapy. J Nucleic Acids 2010:e920161.

Redon CE, Nakamura AJ, Zhang Y-W, Ji JJ, Bonner WM, Kinders RJ, Parchment RE, Doroshow JH and Pommier Y 
(2010) Histone gammaH2AX and poly(ADP-ribose) as clinical pharmacodynamic biomarkers. Clin Cancer Res 16:4532-4542.

Richard DJ, Cubeddu L, Urquhart AJ, Bain A, Bolderson E, Menon D, White MF and Khanna KK (2011a) HSSB1 interacts directly with the MRN complex stimulating its recruitment to DNA double-strand breaks and its endo-nuclease activity. Nucleic Acids Res 39:3643-3651.

Richard DJ, Savage K, Bolderson E, Cubeddu L, So S, Ghita M, Chen DJ, White MF, Richard K, Prise KM, et al. (2011b) HSSB1 rapidly binds at the sites of DNA double-strand breaks and is required for the efficient recruitment of the MRN complex. Nucleic Acids Res 39:1692-1702.

Ripperger T, Gadzicki D, Meindl A and Schlegelberger B (2009) Breast cancer susceptibility: Current knowledge and implications for genetic counselling. Eur J Med Genet 17:722731.

Roberts SA, Strande N, Burkhalter MD, Strom C, Havener JM, Hasty P and Ramsden DA (2010) Ku is a 5'dRP/AP lyase that excises nucleotide damage near broken ends. Nature 464:1214-1217.

Rogakou EP, Pilch DR, Orr AH, Ivanova VS and Bonner WM (1998) Double-stranded breaks induce Histone H2AX phosphorylation on Serine 139. J Biol Chem 273:5858-5868.

Roszkowski K and Olinski R (2012) Urinary 8-oxoguanine as a predictor of survival in patients undergoing radiotherapy. Cancer Epidemiol Biomarkers Prev 2012:629-635.

Rothkamm K and Horn S (2009) gamma-H2AX as protein biomarker for radiation exposure. Ann Ist Super Sanita 45:265-271.

Roy R, Chun J and Powell SN (2012) BRCA1 and BRCA2: Different roles in a common pathway of genome protection. Nat Rev Cancer 12:68-78.

Rübe CE, Grudzenski S, Kühne M, Dong X, Rief N, Löbrich M and Rübe C (2008) DNA double-strand break repair of blood lymphocytes and normal tissues analysed in a preclinical mouse model: Implications for radiosensitivity testing. Clin Cancer Res 14:6546-55.

Salles D, Mencalha AL, Ireno IC, Wiesmüller L and Abdelhay E (2011) BCR-ABL stimulates mutagenic homologous DNA double-strand break repair via the DNA-end-processing factor CtIP. Carcinogenesis 32:27-34.

Shee C, Cox BD, Gu F, Luengas EM, Joshi MC, Chiu L-Y, Magnan D, Halliday JA, Frisch RL, Gibson JL, et al. (2013) Engineered proteins detect spontaneous DNA breakage in human and bacterial cells. Genes Chromosomes 2:e01222.

Sibanda BL, Chirgadze DY and Blundell TL (2010) Crystal structure of DNA-PKcs reveals a large open-ring cradle comprised of HEAT repeats. Nature 463:118-121.

Siever OM, Heinimann K and Tomlinson IPM (2003) Genomic instability - The engine of tumorigenesis? Perspectives $3: 1-8$.

Sirota NP, Zhanataev AK, Kuznetsova EA, Khizhnyak EP, Anisina EA and Durnev AD (2014) Some causes of interlaboratory variation in the results of comet assay. Mutat Res Genet Toxicol Environ Mutagen 770:16-22.
Skiöld S, Naslund I, Brehwens K, Andersson A, Wersall P, Lidbrink E, Harms-Ringdahl M, Wojcik A and Haghdoost S (2013) Radiation-induced stress response in peripheral blood of breast cancer patients differs between patients with severe acute skin reactions and patients with no side effects to radiotherapy. Mutat Res Genet Toxicol Environ Mutagen 756:152-157.

Sleeth KM, Sørensen CS, Issaeva N, Dziegielewski J, Bartek J and Helleday T (2007) RPA mediates recombination repair during replication stress and is displaced from DNA by checkpoint signalling in human cells. J Mol Cell Biol 373:38-47.

Smirnov DA, Brady L, Halasa K, Morley M, Solomon S and Cheung VG (2012) Genetic variation in radiation-induced cell death. Genome Res 22:332-339.

Somaiah N, Yarnold J, Lagerqvist A, Rothkamm K and Helleday T (2013) Homologous recombination mediates cellular resistance and fraction size sensitivity to radiation therapy. Radiother aOncol 108:155-161.

Turesson I, Nyman J, Holmberg E and Oden A (1996) Prognostic factors for acute and late skin reactions in radiotheraphy patients. Int J Radiat Oncol Biol Phys 36:1065-1075.

Voduc KD, Cheang MCU, Tyldesley S, Gelmon K, Nielsen TO and Kennecke H (2010) Breast cancer subtypes and the risk of local and regional relapse. J Clin Oncol 28:1684-1691.

Vral A, Willems P, Claes K, Poppe B, Perletti ABG and Thierens $\mathrm{H}$ (2011) Combined effect of polymorphisms in $\operatorname{Rad} 51$ and $\mathrm{XRCC} 3$ on breast cancer risk and chromosomal radiosensitivity. Mol Med Rep 185:901-912.

Walker JR, Corpina RA and Goldberg J (2001) Structure of the $\mathrm{Ku}$ heterodimer bound to DNA and its implications for double-strand break repair. Nature 412:607-614.

West SC (2003) Molecular views of recombination proteins and their control. Nat Rev 4:1-11.

Williams AB and Michael WM (2010) Eviction notice: New insights into Rad51 removal from DNA during homologous recombination. Mol Cell 37:157-158.

Williams GJ, Hammel M, Radhakrishnan SK, Ramsden D, LeesMiller SP and Tainer JA (2014) Structural insights into NHEJ: Building up an integrated picture of the dynamic DSB repair super complex, one component and interaction at a time. DNA Repair 17:110-120.

Youlden DR, Cramb SM, Dunn NAM, Muller JM, Pyke CM and Baade PD (2012) The descriptive epidemiology of female breast cancer: An international comparison of screening, incidence, survival and mortality. Cancer Epidemiol $36: 237-48$.

\section{Internet Resources}

http://www.cancer.gov/cancertopics/treatment/types/radiationtherapy/radiation-fact-sheet (March $\left.1^{\text {th }}, 2015\right)$.

Associate Editor: Carlos F. M. Menck

This is an open-access article distributed under the terms of the Creative Commons Attribution License (type CC-BY), which permits unrestricted use, distribution and reproduction in any medium, provided the original article is properly cited. 